\title{
Determination of Gold in Various Environment Samples by Flame Atomic Absorption Spectrometry Using Dispersive Liquid-Liquid Microextraction Sampling
}

\author{
Şerife Saçmacı, ${ }^{*}$ Şenol Kartal, and Gülçin Kalkan \\ Erciyes University, Department of Chemistry, Faculty of Sciences, \\ TR-38039, Kayseri, TURKEY
}

RECEIVED DECEMBER 26, 2013; REVISED OCTOBER 13, 2014; ACCEPTED FEBRUARY 13, 2015

\begin{abstract}
A new dispersive liquid-liquid microextraction separation/preconcentration procedure as a rapid sample-preparation technique is proposed for detection of ultra trace amounts of $\mathrm{Au}(\mathrm{III})$ in various media by flame atomic absorption spectrometry using 1,5-diphenyl-1,3,5-pentanetrione as chelating agent. Carbon tetrachloride and methanol were used as extraction and dispersive solvents, respectively. Various parameters that affect the extraction efficiency such as $\mathrm{pH}$, centrifugation rate and time, chelating agent concentration and sampling volume on the recovery of $\mathrm{Au}(\mathrm{III})$ were investigated. Under optimum conditions, the enhancement factor of 750 , relative standard deviation of $2.7 \%$ and calibration graphs obtained in the concentration range of $0.04-5.6 \mu \mathrm{g} \mathrm{L}^{-1}$ for gold were obtained. The limit of detection was $1.1 \mathrm{ng} \mathrm{L}^{-1}$. The accuracy of the method was performed by analysis of the certified reference material (CDN-PGMS-10). The developed method was applied successfully to the determination of gold in the catalytic converter, anode slime, ore and seawater samples. The results show that dispersive liquid-liquid microextraction procedure is sensitive, rapid, simple and safe for the separation/preconcentration of gold from complex sample media.
\end{abstract}

Keywords: gold, dispersive liquid-liquid microextraction, 1,5-diphenyl-1,3,5-pentanetrione, atomic absorption spectrometry

\section{INTRODUCTION}

Gold is one of the precious metals and extensively used in various areas. It is a nonessential toxic element, and some reports about allergic eczematous dermatitis as well as some nephrotoxic effects have been published. ${ }^{1}$ Gold is widely distributed in nature and the chemistry of gold remains an active research area. ${ }^{2}$ The significance of developing accurate and dependable analytical procedures for gold determination is related to its increasing presence in the environment, biology, industry and to a growing interest in the elucidation of its role in living organisms and the impact on human health. ${ }^{3-5}$ Gold could be used as a drug in the supervised therapy of arthritis and cancer in the form of different $\mathrm{Au}(\mathrm{I})$ and $\mathrm{Au}(\mathrm{III})$ compounds, or in radiotherapy of cancer in the form of radioactive isotope ${ }^{198} \mathrm{Au}$. It may be also very toxic for human and animal organism and plants and accounts as a pollutant, ${ }^{5}$ because of its inhibiting effect upon the activity of many enzymes and its preventing effect upon DNA separation. ${ }^{6}$
In natural samples, $\mathrm{Au}$ concentration is about $4 \mathrm{ng} \mathrm{g}^{-1}$ in basic rocks and $1 \mathrm{ng} \mathrm{g}^{-1}$ in soils. The values of 0.05 and $0.2 \mathrm{ng} \mathrm{mL}^{-1}$ were found in sea and river waters, respectively. ${ }^{7}$ Furthermore, because of different matrices and numerous interferences, the direct application of even highly sensitive and selective spectrometric techniques is seriously limited. For this reason, much attention has been paid for the elimination of matrix effects, particularly those coming from common elements present in examined samples, when the AAS detection method is used. ${ }^{8}$

The concentration of gold in environmental, geological and metallurgical materials is usually too low to be determined directly by AAS owing to insufficient sensitivity and matrix interferences. Therefore, a separation and preconcentration stage is often necessary for sensitive and interference-free gold determination. ${ }^{9-12}$

Various techniques have been used for separation and preconcentration of gold from different media, e.g., liquid-liquid extraction, ${ }^{13}$ dispersive liquid-liquid microextraction, ${ }^{14}$ solid-phase extraction, ${ }^{15,16}$ cloud point

\footnotetext{
* Author to whom correspondence should be addressed. (E-mail: sacmaci@erciyes.edu.tr)
} 
extraction, ${ }^{17,18}$ coprecipitation, ${ }^{19}$ electrodeposition, ${ }^{20}$ and ion exchange. ${ }^{21}$

Modern trends in analytical chemistry are towards the simplification and miniaturization of sample preparation procedures as well as the minimization of solvent and reagent consumption. ${ }^{22,23}$ Unconventional liquid-liquid extraction (LLE) methodologies have been arisen like: single drop microextraction (SDME), ${ }^{24}$ wetting film extraction (WFE), ${ }^{25}$ and dispersive liquidliquid microextraction (DLLME). ${ }^{26-30}$ Simplicity, rapidity, low sample volume, low cost, high recovery and enrichment factors are some advantages of DLLME and the technique has also been applied for the determination of trace organic pollutants as well as metal ions in various samples. ${ }^{31,32}$

In the study reported here, we developed a new dispersive liquid-liquid microextraction (DLLME) procedure combined with FAAS by applying a microsample introduction system for the final measurement of $\mathrm{Au}$ (III) ions. By using this method, low volumes of extraction solvent $(20 \mu \mathrm{L})$ can be used without loss of sensitivity. The aim of this study was to exhibit the application of the proposed technique for the rapid determination of gold at trace concentrations. The developed method was successfully applied to the real samples.

\section{EXPERIMENTAL}

\section{Apparatus}

A PerkinElmer (Norwalk, CT, USA) model AAnalyst 800 flame atomic absorption spectrometer equipped with a deuterium background correction system and an air-acetylene burner was used for the determination of gold. The wavelength used for gold was $242.8 \mathrm{~nm}$. Spectral bandwidth of $0.2 \mathrm{~nm}$, acetylene flow rate of $1.4 \mathrm{~L} \mathrm{~min}^{-1}$, and nebulizer flow rate of $10 \mathrm{~mL} \mathrm{~min}^{-1}$ were conventional working parameters. A Consort model $\mathrm{C} 533 \mathrm{pH}$ meter with a combination $\mathrm{pH}$ electrode and an MLTW model 54 centrifuge were employed throughout the experiments.

\section{Reagents and Solutions}

All reagents used in this study were of analytical reagent grade. $\mathrm{Au}(\mathrm{III})$ standard solution of $1000 \mathrm{mg} \mathrm{L}^{-1}$ was purchased from Merck (Darmstadt, Germany). The working solutions of gold were obtained by appropriate dilution of the stock solution. Deionized water was used for the preparation of the solutions. The $1 \%(w / v)$ 1,5-diphenyl-1,3,5-pentanetrione (DPT) solution was prepared by dissolving $1 \mathrm{~g}$ of the reagent in $100 \mathrm{~mL}$ of methanol. The glassware used was cleaned by soaking overnight in dilute $\mathrm{HNO}_{3}(1: 5, v / v)$, and then rinsed with deionized water several times.

\section{Preparation of Samples}

The CRM used was obtained from CDN Resource Laboratories Ltd., British Columbia, Canada. The ore was supplied by Stillwater Mining Corporation from the Still water Complex in Montana, USA, and has a gold concentration of $0.307 \pm 0.044 \mathrm{mg} \mathrm{kg}{ }^{-1}$. A $1.000-\mathrm{g}$ portions of CDN-PGMS-10 standard reference material were transferred into PTFE beakers, and $6 \mathrm{~mL}$ of concentrated $\mathrm{HNO}_{3}$ and $18 \mathrm{~mL}$ of concentrated $\mathrm{HCl}$ were added and heated until the solution becomes transparent, and then it was continued to heating to near dryness. The residue was dissolved in $0.1 \mathrm{~mol} \mathrm{~L}^{-1} \mathrm{HNO}_{3}$ and made up to $10 \mathrm{~mL}$, and then the preconcentration procedure given below, after adjusting their pHs to 4.5, was applied to these sample solutions.

A $0.100-\mathrm{g}$ crushed and ground portion of the catalytic converter, anode slime, leach and filter samples obtained from Organized Industrial Distinct of Kayseri, Turkey, was weighed into a beaker. In order to decompose, $10 \mathrm{~mL}$ of aqua regia was added to the beaker and the mixture was heated until to almost dryness. Then, $10 \mathrm{~mL}$ of aqua regia was added again to the residue and the mixture was evaporated to near dryness. After the moisty residue taking into the solution with $0.1 \mathrm{~mol} \mathrm{~L}^{-1} \mathrm{HNO}_{3}$, the insoluble part of the sample was filtered through a blue ribbon filter paper. Finally, the volume of the filtrate was completed to $10 \mathrm{~mL}$ with $0.1 \mathrm{~mol} \mathrm{~L}^{-1} \mathrm{HNO}_{3}$. After adjusting the $\mathrm{pHs}$ to 4.5 , the preconcentration procedure given below was applied to these sample solutions. Analyses for the blanks were carried out in the same way. The measurement of $\mathrm{Au}(\mathrm{III})$ ions in the final solutions was performed by FAAS.

\section{Procedure}

Under the optimized experimental conditions, aliquots of $10 \mathrm{~mL}$ of sample solution, which were adjusted to the optimum $\mathrm{pH}$ of 4.5 , containing $\mathrm{Au}(\mathrm{III})$ were placed into $50-\mathrm{mL}$ glass test tubes with screw cap, which have conic bottom. A mixture of $80 \mu \mathrm{L}$ of methanol (disperser solvent), $0.25 \mathrm{~mL}$ of $0.1 \%$ 1,5-diphenyl1,3,5-pentanetrione (DPT) solution (chelating agent) (Figure 1) in methanol and $20 \mu \mathrm{L}$ of carbon tetrachloride (extraction solvent) was rapidly injected into the sample solution by using a microsyringe. A cloudy solution (water, methanol, and carbon tetrachloride) was formed in the test tube. In this step, Au(III) reacted with DPT and the formed complex was extracted into the fine droplets of carbon tetrachloride. Then, the solution was centrifuged at $3200 \mathrm{rpm}$ for $4 \mathrm{~min}$, and the dispersed fine droplets of carbon tetrachloride were deposited at the bottom of conical test tube. $20 \mu \mathrm{L}$ of the sedimented phase was removed using a microsyringe. In order to determine the gold in the 
<smiles>O=C(CC(=O)c1ccccc1)CC(=O)c1ccccc1</smiles>

Figure 1. The structure of the chelating agent (DPT).

carbon tetrachloride phase, a $20-\mu \mathrm{L}$ aliquot of this solution was introduced to the nebulizer of the flame atomic absorption spectrometer by using the micro injection method. ${ }^{33}$ The gold signals were measured in the peak area mode utilizing the instrument software. The calibration graph was constructed against aqueous standards by submitting to the same DLLME procedure. Blank determinations were carried out in exactly the same way as the measurements made for sample and calibration standards.

\section{RESULTS AND DISCUSSION}

\section{Characterisation of the Complex}

The stoichiometry of the developed complex, $\mathrm{Au}(\mathrm{III})$ : DPT in $\mathrm{CCl}_{4}$, was determined by the mole-ratio method. ${ }^{34}$ The DPT reagent gives the maximum absorbance at $331 \mathrm{~nm}$ while $\mathrm{Au}(\mathrm{III})$ : DPT complex gives the maximum absorbance at $385 \mathrm{~nm}$, and the complex is colourless. The reagent blank does not show any absorbance at this wavelength. The amount of $\mathrm{Au}(\mathrm{III})$ in the organic phase was estimated spectrophotometrically at $385 \mathrm{~nm}$. The absorbance of the complex against the mole fraction of $\mathrm{Au}(\mathrm{III})$ gave a graph that indicates the formation of the Au(III)-DPT complex having a metal : ligand ratio of exactly $1: 2$, which was assumed by using the mole-ratio method.

The IR spectrum of the extracted complex shows that the stretching frequencies of the carbonyl groups in the DPT reagent appear at 1590, 1552 and $1457 \mathrm{~cm}^{-1}$ have shifted to 1589,1563 and $1409 \mathrm{~cm}^{-1}$, respectively. This indicates that the carbonyl groups are involved in bonding during the complex formation (Figure 2).

\section{Effect of pH}

Separation of metal ions by DLLME technique involves first the formation of complex with sufficient hydrophobicity to be extracted into organic phase, thus, to attain the desired preconcentration. The $\mathrm{pH}$ of the sample solution is one of the most important factors affecting the formation of complexes and the subsequent extraction. The effect of $\mathrm{pH}$ on the DLLME procedure was studied over the $\mathrm{pH}$ range of $1-8$. As can be seen in Figure 3, the quantitative recovery was achieved over the $\mathrm{pH}$ range of $4-5$. In more acidic

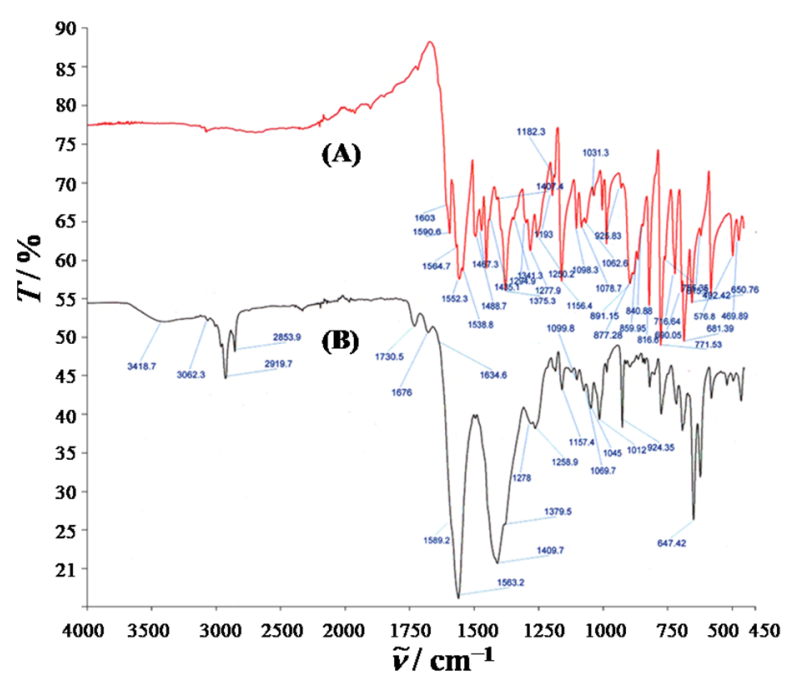

Figure 2. The IR spectra of the DPT (A) and the Au(III)-DPT complex (B).

media $(\mathrm{pH}<3$ ), the formation of the complex was incomplete because of possible competition of hydrogen ions. While the increasing $\mathrm{pH}$ beyond $\mathrm{pH} 5$ caused a decrease in absorbance intensity probably due to instability of the Au(III)-DPT complex. Therefore, $\mathrm{pH}$ 4.5 was selected for the further studies.

\section{Effect of Type and Amount of Extraction Solvent}

The type of extraction solvent used in DLLME procedure is selected on the basis of higher density rather than water, extraction capability of interested compounds, and low solubility in water for efficient microextraction. Chloroform $\left(\mathrm{CHCl}_{3}\right)$ and carbon tetrachloride $\left(\mathrm{CCl}_{4}\right)$ were tested as extraction solvents (20 $\mu \mathrm{L})$ using methanol, aceton and acetonitrile as disperser solvent (about $80 \mu \mathrm{L}$ ). Also, $0.25 \mathrm{~mL}$ of $0.1 \%$ DPT in methanol was used to achieve about $20 \mu \mathrm{L}$ volume of the sedimented phase. When $\mathrm{CHCl}_{3}$ was used

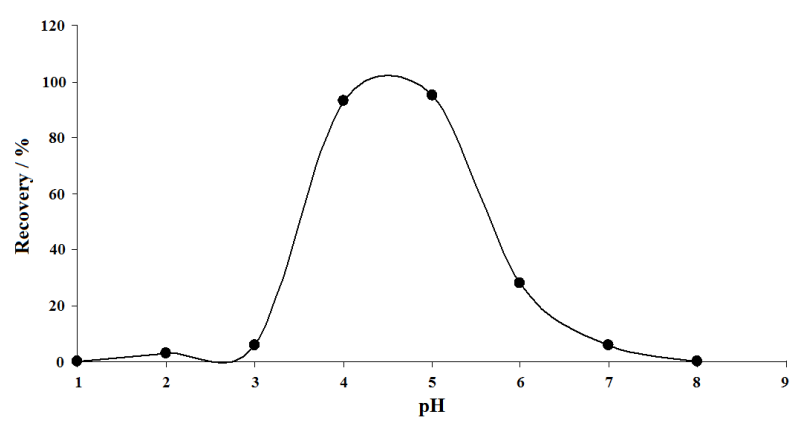

Figure 3. Effect of $\mathrm{pH}$ of the sample solution on the recovery of $\mathrm{Au}(\mathrm{III})$ ions. Type and amount of extraction solvent: $20 \mu \mathrm{L}$ of $\mathrm{CCl}_{4}$, type and amount of disperser solvent: $80 \mu \mathrm{L}$ of methanol, amount of $0.1 \%$ DPT solution in methanol: $0.25 \mathrm{~mL}$, centrifugation time and rate: $4 \mathrm{~min}$ and $3200 \mathrm{rpm}$. 


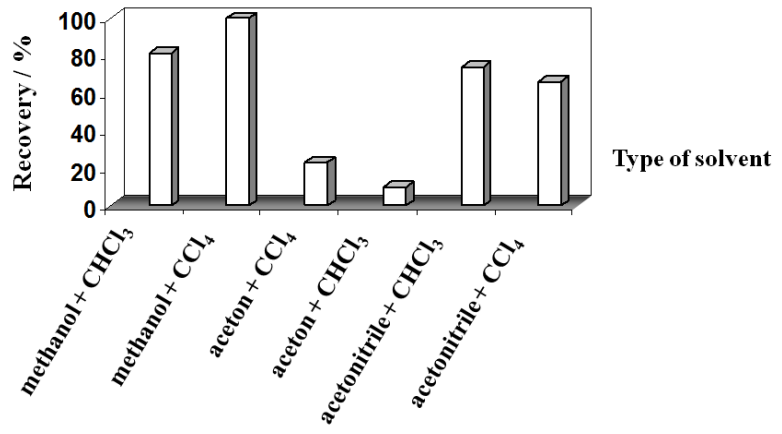

Figure 4. Effect of type of the solvents on the recovery of $\mathrm{Au}(\mathrm{III})$ ions $(n=3)$. pH $4.5 \mathrm{CH}_{3} \mathrm{COOH} / \mathrm{CH}_{3} \mathrm{COONa}$, type and amount of extraction solvent: $20 \mu \mathrm{L}$ of $\mathrm{CCl}_{4}$, type and amount of disperser solvent: $80 \mu \mathrm{L}$ of methanol, amount of $0.1 \%$ DPT solution in methanol: $0.25 \mathrm{~mL}$, centrifugation time and rate: $4 \mathrm{~min}$ and $3200 \mathrm{rpm}$.

as extraction solvent, an unstable cloudy solution was obtained and it was difficult to separate the sedimented phase from the aqueous solution. However, $\mathrm{CCl}_{4}$ and methanol pair gave the best results and they were chosen as the extraction and disperser solvents, respectively, for the further experiments (Figure 4).

In order to examine the effect of volume of the extraction solvent, different volumes of $\mathrm{CCl}_{4}$ changing from 10 to $600 \mu \mathrm{L}$ were subjected to the same DLLME procedure. The quantitative recoveries were obtained from 10 to $200 \mu \mathrm{L}$ of $\mathrm{CCl}_{4}$ (Figure 5). Thereby, $20 \mu \mathrm{L}$ $\mathrm{CCl}_{4}$ was chosen as optimal volume of the extraction solvent in the subsequent experiments. The preconcentration factor for the proposed method was found to be 750 when the experiments were made with a $15-\mathrm{mL}$ of aqueous sample.

\section{Effect of the Amount of 1,5-Diphenyl-1,3,5-pentane- trione}

The effect of the amount of $0.1 \%(w / v)$ 1,5-diphenyl1,3,5-pentanetrione (DPT) solution on the extraction

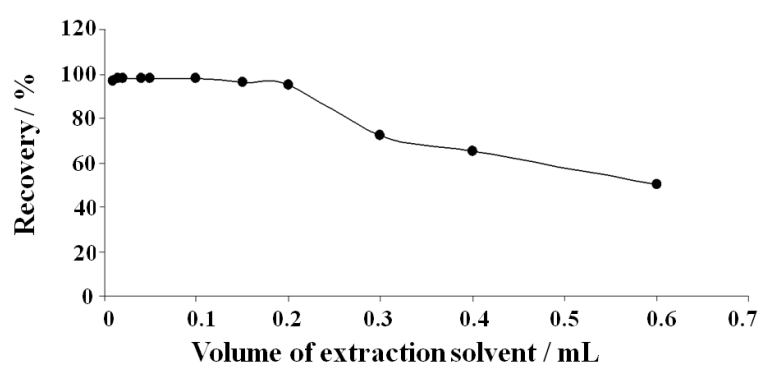

Figure 5. Effect of the amount of the extraction solvent on the recovery of $\mathrm{Au}(\mathrm{III})$ ions $(n=3) . \mathrm{pH}=4.5$ $\mathrm{CH}_{3} \mathrm{COOH} / \mathrm{CH}_{3} \mathrm{COONa}$, type and amount of disperser solvent: $80 \mu \mathrm{L}$ of methanol, amount of $0.1 \%$ DPT solution in methanol: $0.25 \mathrm{~mL}$, centrifugation time and rate: $4 \mathrm{~min}$ and $3200 \mathrm{rpm}$.

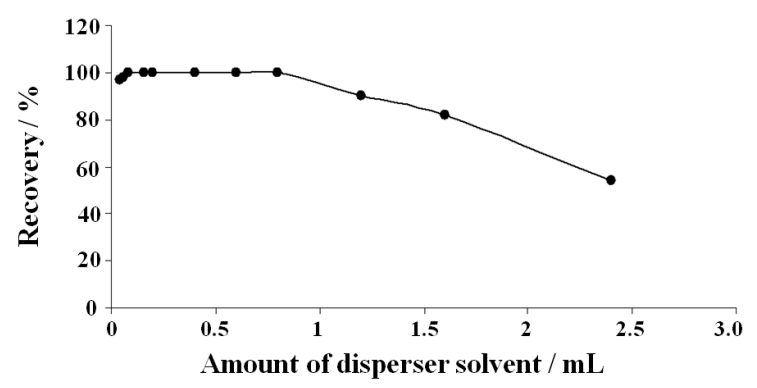

Figure 6. Effect of amount of disperser solvent on the recovery of $\mathrm{Au}$ (III) ions $(n=3) . \mathrm{pH} 4.5 \mathrm{CH}_{3} \mathrm{COOH} /$ $\mathrm{CH}_{3} \mathrm{COONa}$, type and amount of extraction solvent: $20 \mu \mathrm{L}$ of $\mathrm{CCl}_{4}$, amount of $0.1 \%$ DPT solution in methanol: $0.25 \mathrm{~mL}$, centrifugation time and rate: $4 \mathrm{~min}$ and $3200 \mathrm{rpm}$.

efficiency of the DLLME method for the determination of $\mathrm{Au}(\mathrm{III})$ was investigated for the amounts of the reagent varying from 0.05 to $1 \mathrm{~mL}$. The results showed that the recoveries for $\mathrm{Au}(\mathrm{III})$ ions increased quickly up to $0.25 \mathrm{~mL}$ of the reagent solution. As can be seen from Figure 7, the optimum amount of the reagent was chosen to be $0.25 \mathrm{~mL}$ and this amount was used in the subsequent experiments.

\section{Effect of the Centrifugation Rate and Time}

One of the most effective parameters for the DLLME procedure was the centrifugation rate. For this purpose, a series of experiments were made at different centrifugation rates varying from 1500 to $3500 \mathrm{rpm}$ for 4 minutes. The recoveries (\%) were constant between 1500 and $2500 \mathrm{rpm}$ centrifugation rate but low and then slowly increaed up to $3000 \mathrm{rpm}$ giving quantitative results, and remained constant again up to $3500 \mathrm{rpm}$. By taking into consideration these variations, as the optimal centrifugation rate, the $3200 \mathrm{rpm}$ was selected for the further experiments.

The influence of the centrifugation time on the efficiency of the proposed dispersive liquid-liquid microextraction procedure was also studied. The results showed that the maximum extraction efficiency was obtained when the centrifugation time was maintained between 4 and $20 \mathrm{~min}$. If the period of centrifugation is

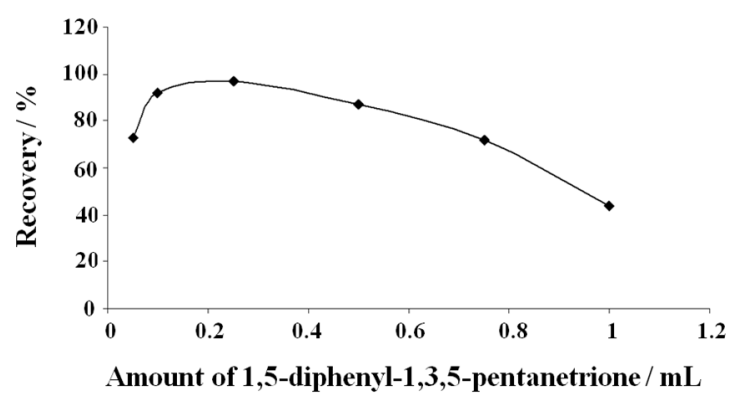

Figure 7. Effect of the amount of 1,5-diphenyl-1,3,5pentanetrione $(0.1 \%, w / v)$ on the recovery of $\mathrm{Au}(\mathrm{III})$ ions. 


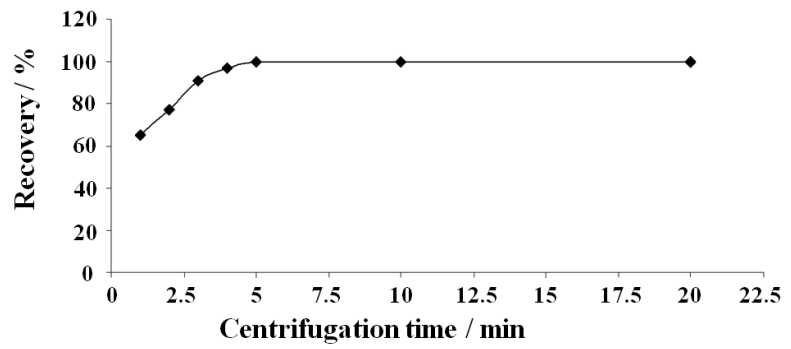

Figure 8. Effect of the centrifugation time on the recovery of $\mathrm{Au}(\mathrm{III})$ ions.

less than $4 \mathrm{~min}$, the analytical signal decreases sharply. Presumably this is due to the dispersion of droplets of the extraction solvent in the aqueous phase. To enable a rapid procedure, an important feature in many analytical applications, the centrifugation time was chosen to be 4 minutes for all the subsequent experiments (Figure 8).

\section{Effect of Foreign Ions}

The effect of various ions in the proposed dispersive liquid-liquid microextraction procedure was studied under the optimized conditions. In these experiments, solutions containing $1 \mathrm{mg} \mathrm{L}^{-1} \mathrm{Au}(\mathrm{III})$ and the interfering species were treated according to the recommended procedure. The tolerance limits of the foreign ions are defined as the largest amount making the recovery of $\mathrm{Au}$ less than $95 \%$, are illustrated in Table 1, which shows the studied substances and their maximum

Table 1. The influences of some ions on the microextraction of $\mathrm{Au}(\mathrm{III})(n=3)$

\begin{tabular}{cccc}
\hline Ions & Added as & $\begin{array}{c}\text { Concentration } / \\
\left(\mathrm{mg} \mathrm{L}^{-1}\right)\end{array}$ & $\begin{array}{c}\text { Recovery } \pm \\
s^{(\mathrm{a})} / \%\end{array}$ \\
\hline $\mathrm{Na}^{+}$ & $\mathrm{NaNO}_{3}$ & 12500 & $97 \pm 1$ \\
$\mathrm{~K}^{+}$ & $\mathrm{KNO}_{3}$ & 1000 & $95 \pm 1$ \\
$\mathrm{Ca}^{2+}$ & $\mathrm{Ca}\left(\mathrm{NO}_{3}\right)_{2} \cdot 4 \mathrm{H}_{2} \mathrm{O}$ & 2500 & $95 \pm 2$ \\
$\mathrm{Mg}^{2+}$ & $\mathrm{Mg}\left(\mathrm{NO}_{3}\right)_{2} \cdot 6 \mathrm{H}_{2} \mathrm{O}$ & 2500 & $99 \pm 1$ \\
$\mathrm{Zn}^{2+}$ & $\mathrm{Zn}\left(\mathrm{NO}_{3}\right)_{2}$ & 10 & $96 \pm 1$ \\
$\mathrm{Fe}^{3+}$ & $\mathrm{Fe}\left(\mathrm{NO}_{3}\right)_{3} \cdot 6 \mathrm{H}_{2} \mathrm{O}$ & 10 & $97 \pm 2$ \\
$\mathrm{Ni}^{2+}$ & $\left.\mathrm{Ni}^{2+} \mathrm{NO}_{3}\right)_{2}$ & 10 & $98 \pm 1$ \\
$\mathrm{Cd}^{2+}$ & $\mathrm{Cd}\left(\mathrm{NO}_{3}\right)_{2}$ & 10 & $93 \pm 1$ \\
$\mathrm{Al}^{3+}$ & $\mathrm{Al}\left(\mathrm{NO}_{3}\right)_{3}$ & 10 & $94 \pm 2$ \\
$\mathrm{~Pb}^{2+}$ & ${\mathrm{Pb}\left(\mathrm{NO}_{3}\right)_{2}}_{\mathrm{Mn}^{2+}}$ & 10 & $95 \pm 1$ \\
$\mathrm{Mr}^{3+}\left(\mathrm{NO}_{3}\right)_{2}$ & 10 & $94 \pm 2$ \\
$\mathrm{Cu}^{2+}$ & $\mathrm{Cr}\left(\mathrm{NO}_{3}\right)_{3}$ & 10 & $96 \pm 3$ \\
$\mathrm{Cl}^{-}$ & $\left.\mathrm{NO}_{3}\right)_{2} \cdot 4 \mathrm{H}_{2} \mathrm{O}$ & 10 & $92 \pm 2$ \\
$\mathrm{SO}_{4}{ }^{2-}$ & $\mathrm{NaCl}_{\mathrm{Na}_{2} \mathrm{SO}_{4}}$ & 10000 & $99 \pm 1$ \\
$\mathrm{H}_{2} \mathrm{PO}_{4}^{-}$ & $\mathrm{NaH}_{2} \mathrm{PO}_{4} \cdot 2 \mathrm{H}_{2} \mathrm{O}$ & 5000 & $97 \pm 2$ \\
\hline $\mathrm{Standa}^{2+}$ & & & $101 \pm 2$ \\
\hline
\end{tabular}

(a) Standard deviation. tolerable amounts. The criterion for the interference of each species was set at $\pm 5 \%$ in the analytical signal obtained from a solution containing gold, without any interfering. Large amounts of alkaline and alkaline earth metal ions had no interference with the DLLME method under the optimum conditions due to probably low stabilities of their 1,5-diphenyl-1,3,5-pentanetrione complexes. The other metal ions and some common anions didn't show any interfering effect at their studied levels for the determination of gold(III) in various samples.

\section{Analytical Features}

The analytical characteristics of the proposed procedure were carried out under the optimized conditions. The equation of the calibration curve obtained after applying the preconcentration procedure was $A=0.0339 C_{\mathrm{Au}}+$ 0.0102 , where $A$ is absorbance and $C_{\mathrm{Au}}$ is gold concentration. Linearity was observed over the range 6.5-64 $\mu \mathrm{g} \mathrm{L}^{-1}$ with a determination coefficient $\left(r^{2}\right)$ of 0.9970 . The limit of detection (LOD), based on $3 s$, was $1.1 \mathrm{ng} \mathrm{L}^{-1}$. The precision of the method was found to be $2.7 \%$ as the relative standard deviation by analyzing ore samples $(n=8)$. A preconcentration factor of 750 was achieved.

\section{Accuracy}

To verify the accuracy of the proposed method, the Au content of the certified reference material (CDN-PGMS10) was determined by the proposed method. As can be seen in Table 2, the obtained results were in good agreement with the reference value.

Table 2. The determination of $\mathrm{Au}(\mathrm{III})$ in the standard reference material, catalytic converter, ore and seawater samples after the application of the presented procedure $(n=3)$

\begin{tabular}{|c|c|c|c|}
\hline Sample & Added & Found & $R \pm s / \%$ (a) \\
\hline \multirow{4}{*}{$\begin{array}{l}\text { Catalytic } \\
\text { converter / } \\
\mu \mathrm{g} \mathrm{g}^{-1}\end{array}$} & - & - & - \\
\hline & 0.5 & $0.46 \pm 0.08^{(\mathrm{a})}$ & $92 \pm 3$ \\
\hline & 1.0 & $0.96 \pm 0.06$ & $96 \pm 2$ \\
\hline & - & $1.94 \pm 0.05$ & - \\
\hline \multirow[t]{2}{*}{ Ore $/ \mathrm{mg} \mathrm{g}^{-1}$} & 1.0 & $2.83 \pm 0.06$ & $96 \pm 1$ \\
\hline & 2.0 & $3.8 \pm 0.1$ & $97 \pm 2$ \\
\hline \multirow{3}{*}{$\begin{array}{c}\text { Seawater / } \\
\mathrm{mg} \mathrm{L}^{-1}\end{array}$} & - & - & - \\
\hline & 0.5 & $0.48 \pm 0.04$ & $96 \pm 2$ \\
\hline & 1.0 & $0.95 \pm 0.16$ & $95 \pm 2$ \\
\hline $\begin{array}{c}\text { Certified } \\
\text { reference material, } \\
\text { CDN-PGMS-10 / } \\
{\mu \mathrm{g} \mathrm{g}^{-1}}^{-}\end{array}$ & $\begin{array}{l}\text { Certified value } \\
0.307 \pm 0.044\end{array}$ & $0.30 \pm 0.04^{(\mathrm{a})}$ & $98 \pm 1$ \\
\hline
\end{tabular}


Table 3. The concentration of $\mathrm{Au}(\mathrm{III})$ in the various environmental samples $\left(n=3, \mu \mathrm{g} \mathrm{g}^{-1}\right)$

\begin{tabular}{cc}
\hline Sample & Au content $\pm s^{(\mathrm{a})}$ \\
\hline Anode slime & $115 \pm 8$ \\
Catalytic converter & - \\
Ore 1 & $1.94 \pm 0.05$ \\
Ore 2 & $0.99 \pm 0.08$ \\
Ore 3 & $0.09 \pm 0.01$ \\
\hline
\end{tabular}

(a) Standard deviation.

The recovery studies for gold(III) were performed in seawater, ore and converter samples. The known amounts of gold were spiked to the sample solutions in order to estimate the accuracy of the presented procedure (Table 2). Good agreement was obtained between the added and found analyte contents using the recommended procedure.

\section{Analysis of Real Samples}

The proposed method was successfully applied to the determination of $\mathrm{Au}(\mathrm{III})$ in various environmental samples (Table 3).

\section{CONCLUSION}

A new DLLME method combined with FAAS has been proposed for the determination of $\mathrm{Au}$ in catalytic converter, anode slime, ore and seawater samples. In the proposed procedure, the reagent 1,5-diphenyl-1,3,5pentanetrione was successfully used as complexing agent for the preconcentration of gold(III) using the proposed dispersive liquid-liquid microextraction procedure. The method is simple, easy to use, and economical. The low cost is related mainly to small amounts of solvents required. The small amounts of carbon tetrachloride and methanol also minimizes the toxicity of the method. Another interesting feature of the method is speed. As can be shown in Table 4, the characteristic data of the present method are compared with those reported in the literature. The method is sensitive, reproducible, and has a lower limit of detection and higher preconcentration factor over the other methods reported in the references. Especially, sample preparation time and consumption of toxic organic solvents are minimized in this method without affecting the sensitivity of the method. In order to introduce the final sample solution to the FAAS by using a micro injection technique, provides an important advantage to get good analytical singals. Also the use of FAAS as a detection system has low cost and operational facilities.

\section{REFERENCES}

1. I. Ott, Coord. Chem. Rev. 253 (2009) 1670-1681.

2. A. S. Amin, Spectrochim. Acta Part A 77 (2010) 1054-1058.

3. R. Dobrowolski, M. Kurylo, M. Otto, and A. Mroz, Talanta 99 (2012) 750-757.

4. Q. Pu, P. Liu, Q. Sun, and Z. Su, Microchim. Acta 143 (2003) 45-51.

5. D. Afzali, A. Mostafavi, and M. Mirzaei, J. Hazard. Mater. 181 (2010) 957-961.

6. S. M. Rancic, S. D. Nikolic-Mandic, and L. M. Mandic, Anal. Chim. Acta 547 (2005) 144-149.

7. J. Medved, M. Bujdos, P. Matus, and J. Kubova, Anal. Bioanal. Chem. 379 (2004) 60-65.

8. M. Balcerzak, Anal. Sci. 18 (2002) 737-750.

9. A. K. Das, M. Dutta, M. L. Cervera, and M. de la Guardia, Microchem. J. 86 (2007) 2-8.

10. K. Pyrzynska, Spectrochim. Acta Part B 60 (2005) 1316-1322.

11. I. de la Calle, F. Pena-Pereira, N. Cabaleiro, I. Lavilla, and C. Bendicho, Talanta 84 (2011) 109-115.

Table 4. Comparison of the results of the proposed method with the other published works for the determination of gold

\begin{tabular}{|c|c|c|c|c|c|c|c|}
\hline $\begin{array}{l}\text { Preconcentra- } \\
\text { tion method }\end{array}$ & Samples & Technique & Reagent / solvent & $\begin{array}{l}\mathrm{LOD} / \\
\mu \mathrm{g} \mathrm{L}^{-1}\end{array}$ & $\mathrm{RSD} / \%$ & $\mathrm{PF}$ & Reference \\
\hline SPE & Water samples & FAAS & $\begin{array}{l}\text { 5-(4-dimethylamino } \\
\text { benzyliden)-rhodanine }\end{array}$ & 0.1 & 2.3 & 105 & 5. \\
\hline SPE-FIA & $\begin{array}{l}\text { Alloy and anode } \\
\text { slime }\end{array}$ & FAAS & Amidinothioureido-silica gel & 13 & $1.2(n=11)$ & - & 33. \\
\hline DLLME & $\begin{array}{l}\text { Tap water and } \\
\text { silicate ore } \\
\text { samples }\end{array}$ & ETAAS & Victoria blue / chlorobenzene & 5 & $4.2(n=8)$ & 388 & 34. \\
\hline DLLME & & ETAAS & Dicyclohexylamine $/ \mathrm{CHCl}_{3}$ & 0.002 & - & 60 & 35. \\
\hline $\mathrm{CPE}$ & Mine stone & ICP-OES & $\begin{array}{c}\text { o,o-diethyl dithio phosphate / } \\
\text { Triton X-114 }\end{array}$ & 0.5 & $<5$ & 8.6 & 36. \\
\hline DLLME & $\begin{array}{l}\text { Natural water } \\
\text { and hair sam- } \\
\text { ples. }\end{array}$ & ETAAS & $\begin{array}{c}\text { N-(4-\{4-[(anilinocarbo- } \\
\text { thioyl)amino]benzyl }\} \text { phenyl)- } \\
\text { N-phenylthiourea / } \\
\text { 1-hexyl-3-methylimidazo-lium } \\
\text { hexafluorophosphate }\end{array}$ & 0.0048 & 4.1 & 48.7 & 37. \\
\hline DLLME & $\begin{array}{l}\text { Converter, } \\
\text { anode slime, ore } \\
\text { sample }\end{array}$ & FAAS & $\begin{array}{c}\text { 1,5-diphenyl-1,3,5- } \\
\text { pentanetrione / } 80 \mu \mathrm{L} \text { of } \\
\text { methanol }+20 \mu \mathrm{L} \text { of } \mathrm{CCl}_{4}\end{array}$ & 0.0011 & 2.7 & 750 & $\begin{array}{l}\text { This } \\
\text { work }\end{array}$ \\
\hline
\end{tabular}


12. S. S. Bozkurt and M. Merdivan, Environ. Monit. Assess. 158 (2009) 15-21.

13. Z. Tu, S. Lu, X. Chang, Z. Li, Z. Hu, L. Zhang, and H. Tian, Microchim. Acta 173 (2011) 231-239.

14. J. Hassan, M. Shamsipur, and M. Karbasi, Microchem. J. 99 (2011) 93-96.

15. O. C. Bosch and R. F. Sanchez, Anal. Bioanal. Chem. 394 (2009) 759-782.

16. J. L. Manzoori, H. Abdolmohammad-Zadeh, and M. Amjadi, Microchim. Acta 159 (2007) 71-78.

17. H. Sato and J. Ueda, Analytical Sci. 16 (2000) 1089-1090.

18. M. E. Kiziroglou, M. A. Goswami, R. W. Moseley, P. Taylor, S. Pranonsatita, A. S. Holmesa, and E. M. Yeatman, Proc. SPIE 6882 (2008) 1-9.

19. P. Liu, G. F. Liu, D. L. Chen, S. Y. Cheng, and N. Tang, Trans. Nonferrous Met. Soc. China 19 (2009) 1509-1513.

20. M. A. M. Da Silva, V. L. A. Frescura, and A. J. Curtius, Spectrochim. Acta Part B 56 (2001) 1941-1949.

21. M. Miro, J. M. Estela, and V. Cerda, Curr. Anal. Chem. 1 (2005) 329-343.

22. F. P. Pereira, I. Lavilla, and C. Bendicho, Spectrochim. Acta Part B 64 (2009) 1-15.

23. A. N. Anthemidis and I. S. I. Adam, Anal. Chim. Acta $\mathbf{6 3 2}$ (2009) 216-220.

24. I. S. I. Adam and A. N. Anthemidis, Talanta 77 (2009) 1160-1164.
25. E. K. Paleologos, D. L. Giokas, and M. I. Karayannis, Trends Anal. Chem. 24 (2005) 426-436.

26. M. Rezaee, Y. Assadi, M. R. M. Hosseini, E. Aghaee, F. Ahmadi, and S. Berijani, J. Chromatogr. A 1116 (2006) 1-9.

27. A. N. Anthemidis and K. I. G. Ioannou, Talanta 79 (2009) 86-91.

28. E. Z. Jahromi, A. Bidari, Y. Assadi, M. R. M. Hosseini, and M. R. Jamali, Anal. Chim. Acta 585 (2007) 305-311.

29. S. Li, S. Cai, W. Hu, H. Chen, and H. Liu, Spectrochim. Acta, Part B 4 (2009) 666-671.

30. Ş. Saçmacı, Ş. Kartal, and S.. Dural, J. Braz. Chem. Soc. 23 (2012) 1033-1040.

31. L. Elçi, Ş. Kartal, A. Ülgen, M. Doğan, and P. Doğan, Turk. J. Chem. 14 (1990) 294-302.

32. D. A. Skoog, D. M. West, and F. J. Holler, Fundamentals of Analytical Chemistry, Sixth Edition, Saunders College Publishing, Philadelphia, 1992, pp.582-586.

33. S. Zhang, Q. Pu, P. Liu, Q. Sun, and Z. Su, Anal. Chim. Acta 452 (2002) 223-230.

34. M. Shamsipur and M. Ramezani, Talanta 75 (2008) 294-300.

35. S. Kagaya, D. Takata, T. Yoshimori, T. Kanbara, and K. Tohda, Talanta 80 (2010) 1364-1370.

36. L. Tavakoli, Y. Yamini, H. Ebrahimzadeh, A. Nezhadali, S. Shariati, and F. Nourmohammadian, J. Hazard. Mater. 152 (2008) 737-743.

37. H. Ashkenani and T. M. Ali, Microchem. J. 103 (2012) 185-190. 